Jarosław Kupczak OP

Uniwersytet Papieski

Jana Pawła II w Krakowie
Etyka pracy socjalnej w filozofii spotkania i dialogu, red. M. Duda, I. Rybka, H. Kaszyński, Kraków 2017, s. 15-26 (Praca Socjalna w Teorii i Działaniu, 4).

DOI: http://dx.doi.org/10.15633/9788374386425.02

\title{
Personalistyczne podstawy troski o drugiego
}

\section{Personalist foundations of care for others}

\begin{abstract}
Abstrakt: Artykuł przedstawia elementy filozoficznej analizy doświadczenia troski o drugiego, które mogą być odnalezione w refleksji czterech myślicieli, którzy żyli i pracowali w XXwiecznym Krakowie: Romana Ingardena, Antoniego Kępińskiego, Karola Wojtyły i Józefa Tischnera. Troska o drugiego jest jednym z najbardziej podstawowych elementów ludzkiego życia. Egzystencja każdego człowieka jest możliwa tylko dlatego, że od momentu poczęcia szereg osób: rodzice, lekarz, wychowawcy, troszczy się o nowo poczęte i narodzone ludzkie życie. Doświadczenie troski i miłości ze strony innych ludzi objawia każdemu człowiekowi jego duchowe DNA: osobową wartość i godność, które łączą się z byciem osobą (kimś) a nie rzeczą (czymś). Dojrzewanie każdego człowieka jest nie tylko doświadczeniem troski ze strony innych, ale jest też uczeniem

Abstract: The article presents elements of philosophical analysis of the experience of care for others that may be found in the reflection of four thinkers who lived and worked in 20th century Kraków: Roman Ingarden, Antoni Kępiński, Karol Wojtyła and Józef Tischner. Care for the other forms one of the most fundamental elements of human existence. From the moment of conception the existence of every human person is possible only because of many people: parents, doctors, and educators, who care for the newly conceived and born human life. The experience of receiving love and care from others reveals to every human being his or her spiritual DNA: personal worth and dignity that are connected with being a person (somebody) and not something. Personal growth consists not only in receiving care from others, but it is also learning to care for others.
\end{abstract}


się troski o innych. Umiejętność zauważenia cierpienia, biedy i jakiegokolwiek braku u drugiego człowieka oraz zatroszczenia się o niego może być uważana za jedną z podstawowych miar ludzkiej dojrzałości.

Słowa kluczowe: osoba, godność, personalizm, norma personalistyczna, troska o drugiego, ubóstwo.
The ability to notice suffering, poverty or any privation of another person and to take care of him or her can be considered one of the basic measures of human maturity.

Keywords: person, dignity, personalism, personalist norm, concern for others, poverty.

W kwietniu 2007 roku w Krakowie odbyło się sympozjum o znaczącym tytule Krakowska szkoła antropologicna, w czasie którego zostały zarysowane koncepcje człowieka czterech XX-wiecznych krakowskich myślicieli: Romana Ingardena, Antoniego Kępińskiego, Karola Wojtyły i Józefa Tischnera ${ }^{1}$. Prelegentami byli ich uczniowie, dzisiaj już sami oddający miejsce na swoich katedrach swoim uczniom: Adam Węgrzecki, Jacek Bomba, Tadeusz Biesaga i Karol Tarnowski. Oczywiście jednym z powracających pytań konferencji było to o samo istnienie krakowskiej szkoły antropologicznej, czyli o to, co łączy w myśleniu o człowieku te cztery wybitne postaci: Ingarden, Kępiński, Wojtyła, Tischner. Uczestnicy sympozjum zgadzali się, że jest to pewien rys personalistyczny: dociekliwość i wierność w ukazywaniu różnych aspektów podmiotowego życia osoby, niezgoda na jakikolwiek redukcjonizm w ujmowaniu człowieka: biologiczny, historyczny, ekonomiczny, socjologiczny, czy jakikolwiek inny. W tym znaczeniu możemy chyba mówić o istnieniu krakowskiej szkoły personalistycznej. To właśnie odniesienie posłuży nam do mówienia tutaj o personalistycznych podstawach troski o drugiego.

Podstawowe tezy tego wystąpienia chcielibyśmy zaprezentować poprzez wskazanie na szczególnie ważne dla personalizmu teksty biblijne zaczerpnięte $\mathrm{z}$ Nowego Testamentu. Są trzy powody takiej decyzji. Po pierwsze, istnieje związek chrześcijańskiego Objawienia $\mathrm{z}$ historią pojęcia osoby i historią nurtu personalistycznego ${ }^{2}$. Po drugie, krakowski personalizm ma jeszcze inną historię i wcześniejsze od wyżej wskazanych źródła, na które wskazują takie żyjące w ubiegłym wieku w Krakowie osoby jak: Albert Chmielowski, Faustyna Kowalska, Aniela Salawa czy Rozalia Celakówna. Po trzecie, dla wskazanych powyżej przedstawicieli krakowskiej szkoły personalistycznej chrześcijańskie

\footnotetext{
Por. Krakowska szkoła antropologiczna, red. J. Kupczak OP, J. Majka, Kraków 2009.

Por. G. Reale, Metafizyka osoby jako podstawa wychowania, w: Personalistyczny wymiar filozofii wychowania, red. A. Szudra, K. Uzar, Lublin 2009, s. 23-44.
} 
objawienie było istotnym źródłem inspiracji. Nie chodzi tutaj o uprawianie teologii osoby, ale o ukazanie treści chrześcijańskiego objawienia, które mają uniwersalną, humanistyczną wartość.

\section{Co to jest personalizm?}

W Ewangelii według św. Marka znajdujemy wyjątkowy opis uzdrowienia niewidomego człowieka. Zostaje on przyprowadzony do Jezusa z prośbą, aby "go dotknął”. Czytamy dalej w Ewangelii: „On [Jezus] ujął niewidomego za rękę i wyprowadził go poza wieś. Zwilżył mu oczy śliną, położył na niego ręce i zapytał: «Czy widzisz co?». A gdy przejrzał, powiedział: «Widzę ludzi, bo gdy chodzą, dostrzegam ich niby drzewa». Potem znowu położył ręce na jego oczy. I przejrzał on zupełnie, i został uzdrowiony; wszystko widział teraz jasno i wyraźnie" (Mk 8, 23-25).

Opis uzdrowienia uderza swoim personalizmem - to opis spotkania między osobami: dotyk, wzięcie za rękę. Aby dokonać uzdrowienia, Jezus wyprowadza niewidomego poza wieś; chodzi o intymne spotkanie, o chorego i jego cierpienie, a nie o spektakl odegrany przed ciekawskimi. Uzdrowienie niewidomego jest stopniowe, wymaga cierpliwości i oczekiwania, przez co przypomina proces dojrzewania każdego człowieka w relacji do innych ludzi. Najpierw niewidomy zaczyna widzieć ludzi jak „, chodzące drzewa”, dopiero potem widzi wszystko „jasno i wyraźnie”. W myśli personalistycznej, chociażby wybitnego niemieckiego filozofa Roberta Spaemanna, ta umiejętność odróżnienia ludzi od drzew, osób od rzeczy, kogoś od czegoś jest określana jako przebudzenie To przebudzenie człowieka wobec bogactwa świata międzyosobowego jest ważnym elementem ludzkiego dojrzewania, porzuceniem dziecięcego świata, gdzie najważniejszym doświadczeniem jest doświadczenie bezpośredniości własnego „ja”, własnych potrzeb i odczuć, na rzecz doświadczenia także bogactwa „ty”. Empatia i współczucie zamiast ego-centryzmu.

Doświadczenie personalistycznego obudzenia jest obecne w myśli każdego $\mathrm{z}$ wymienionych powyżej myślicieli. Podstawowe przeświadczenie personalizmu Karola Wojtyły, które ukształtowało się bardzo wcześnie w jego życiu, można wyrazić za pomocą tytułu jednego z jego artykułów z lat 60. ubiegłego wieku Człowiek jest osobą ${ }^{4}$. Osoba różni się od każdego innego bytu, także od zwierząt (a może właśnie szczególnie od zwierząt, którym przecież jesteśmy najbliżsi) swoistością swojego życia wewnętrznego. To wewnętrzne życie ducha

3 Por. R. Spaemann, Szczęście a życzliwość. Esej o etyce, tłum. J. Merecki, Lublin 1997, s. $248-250$.

4 Por. K. Wojtyła, Człowiek jest osoba, w: K. Wojtyła, Aby Chrystus się nami posługiwat, Kraków 1979, s. 214-218. 
ludzkiego cechuje się rozumnością i wolnością, pisze Wojtyła, które sprawiają, że ludzkie procesy poznania i pragnienia skierowane są nie tylko w kierunku konkretnych indywidualnych poznań i pragnień, jakie cechują także zwierzęta. Człowiek stawia sobie pytanie o prawdę i dobro w ogóle; w zależności od tych odpowiedzi jest gotów kształtować swoje życie i w wolności ponosić ryzyko jego realizacji, spełnienia bądź nie-spełnienia ${ }^{5}$.

Akt uznania osoby w drugim człowieku Wojtyła nazywa afirmacją. To nie jest proste spojrzenie, „rzucenie okiem”, ale pewien angażujący całą osobę akt - akt etyczny. Spojrzenie na drugą osobę różni się od spojrzenia na kamień i drzewo, samochód czy piękną kamienicę w starym Krakowie; różni się nie tylko swoją treścią, ale i sposobem, w jaki takie spojrzenie jest wyłaniane przez poznający podmiot (do tego tematu jeszcze powrócimy). Druga osoba nie jest prostą sumą przypadłości i cech, które jesteśmy w stanie dostrzec i ocenić, ale jest kimś więcej: odrębnym centrum świata; każde „ja” widziane od strony „ja” jest pewnym środkiem świata.

Akt afirmacji, tego uznania osoby w człowieku, prowadzi do określonego sposobu postępowania wobec innych, które powinno się kierować normą personalistyczną. W książce Wojtyły z 1960 roku Miłość i odpowiedzialność norma personalistyczna sformułowana jest w następujący sposób: „osoba jest takim dobrem, z którym nie godzi się używanie, które nie może być traktowane jako przedmiot użycia i w tej formie jako środek do celu"6. Norma personalistyczna jest zaczerpnięta przez Wojtyłę z myśli Immanuela Kanta, choć ma swoje głębokie korzenie w kulturze Zachodu, chociażby w Augustyńskim rozróżnieniu na $u t i$ i frui - używać i kosztować?.

A więc, zgodnie z normą personalistyczną, osoba nie może być tylko środkiem do celu. Możemy postawić pytanie, czy inne osoby w różnych sytuacjach są dla nas środkami do celu? Oczywiście, że tak. Kierowca tramwaju ma nas zawieźć w określonym czasie do określonego celu, a do sklepu spożywczego większość $\mathrm{z}$ nas chodzi nie po to, aby się zaprzyjaźnić z ekspedientką, ale po to, aby jak najsprawniej zrobić zakupy, czy też jak mówimy - od słowa „sprawnie” - „spra-

To ryzyko dotyczy problemu etyczności osoby ludzkiej, czyli postępowania dobrze bądź źle w znaczeniu moralnym. Człowiek odnoszący sukcesy w swoim życiu zewnętrznym może być równocześnie znieprawiony wewnętrznie bądź głęboko nieszczęśliwy na przykład wskutek przekonania, że rozmija się z prawdziwym celem (powołaniem) swojego życia. Wewnętrzna prawość dotyczy indywidualnego sumienia każdej osoby, wierności bądź sprzeniewierzenia się swojemu sumieniu.

K. Wojtyła, Miłość i odpowiedzialność, Lublin 1986, s. 42.

7 Por. I. Kant, Uzasadnienie metafizyki moralności, tłum. M. Wartenberg, Warszawa 1984, s. 62; por.: J. Kupczak, Dar i komunia. Teologia ciała w ujęciu Jana Pawła II, Kraków 2006, s. 104-106. 
wunki". W takich sytuacjach postępowanie innych osób jest dla nas środkiem do osiągnięcia celu, a nie samo człowieczeństwo kierowcy tramwaju czy ekspedientki w sklepie. W myśli personalistycznej to człowieczeństwo, ta wartość każdej osoby, czy też realizowanie się dobra każdej osoby, ma być celem działania. Jest wartością nieredukowalną i nieutylitarną. To człowieczeństwo jest właściwym miejscem spotkania między osobami, a równocześnie najważniejszym przedmiotem troski o drugiego ${ }^{8}$.

\section{2. „Nie sqadźcie, abyście nie byli sqdzeni” (M† 7, 1). Poznanie rzeczy i poznanie osób}

Ksiądz Józef Tischner był zafascynowany dokonaniami Antoniego Kępińskiego; mówił o jego twórczości, że jest to „pierwsza po polsku odczuta, po polsku napisana, z polskiej dobroci płynąca, a zarazem uniwersalnie mądra, polska filozofia człowieka"9. Szczególnie ważna dla Tischnera była podstawowa zasada krakowskiego psychiatry stosowana zarówno w jego klinice, jak i w indywidualnych spotkaniach z pacjentami: „pozwolić drugiemu być”. Ta zasada „pozwolić innemu być", obecna w personalistycznej myśli Martina Heideggera i Gabriela Marcela, jest warunkiem spotkania $\mathrm{z}$ drugim i poznania drugiego. Jak podkreślał Tischner, poznanie drugiego nie jest automatyczne (w tym znaczeniu ludzie są Leibnitzowskimi „monadami bez okien”), ale wymaga otwarcia się, „otwarcia okien”. Jak pisze krakowski filozof, „otwarcie to musi być dwustronne: nie tylko drugi musi się otworzyć przede mną, lecz także ja muszę w jakimś sensie «otworzyć się dla drugiego». Warunkiem poznania personalnego jest jakaś sytuacja «szczerości», która poprzedza wszelką wymianę słów. Nie jest ona jeszcze poznaniem sensu stricto, ona jest warunkiem poznania"10. Tischnerowskie poznanie drugiego człowieka, podobnie jak Wojtyłowa afirmacja, jest aktem etycznym, angażującym całą osobę.

Otwarcie i szczerość to warunki spotkania i wzajemnego poznania człowieka. Aby opisać możliwość takiego wzajemnego otwarcia się na siebie, Tischner sięga do określenia ethos w jednym z jego etymologicznych znaczeń. Czytamy w słyn-

8 Nierzadko troszczymy się o podstawowe potrzeby drugiej osoby: bezpieczne mieszkanie, jedzenie, ubranie; w niektórych relacjach (przyjaźń, rodzina, małżeństwo) troszczymy się też o moralny charakter drugiej osoby: prawdomówność, słowność, ofiarność, lojalność itp.

9 Cyt. w: J. Galarowicz, Ksiądz Józef Tischner, Kraków 2013, s. 81. Częste używanie przez filozofa z Łopusznej przymiotnika „polski” w pozytywnym znaczeniu tego słowa zdaje się wskazywać na to, że cytat pochodzi z wczesnego okresu twórczości Tischnera.

10 J. Tischner, Myślenie według wartości, Kraków 2011, s. 436. 
nym eseju Filozofia wypróbowanej nadziei (tytuł tego eseju jest Tischnerowskim określeniem myśli Kępińskiego): „Ethos oznacza między innymi miejsce, na którym jakaś roślinka «zadomowiła się», które sobie «oswoiła», naturalne dla niej miejsce pobytu, gdzie czuje się bezpiecznie i nie potrzebuje maskować siebie. Człowiek, jak wszystko, co żyje, szuka swojego ethosu - miejsca zadomowienia i kręgu swojskości. Otwiera się i mówi «od siebie», gdy czuje, że stworzono mu lub sam sobie zdołał stworzyć coś z tej atmosfery. Zamyka się, gdy pogrąża się go w świecie obcym, wrogim, podejrzliwym”. Jak podkreśla Tischner, „poznanie stojącego opodal drzewa może, jak się zdaje, obejść się bez tak pojętego ethosu. Ale gdy go braknie w przypadku odniesienia do drugiego człowieka, poznaniu temu z góry zostaną wytyczone granice"11.

Wzajemne poznanie i otworzenie się na siebie wymaga stworzenia atmosfery bezpieczeństwa i zaufania, czyli przekonania, że ze strony drugiego nie grozi nam żadne niebezpieczeństwo. Ta atmosfera zaufania jest kluczowa w każdym prawdziwym spotkaniu, ale szczególnie w sytuacji troski o drugiego, zwłaszcza kiedy opiekun musi zadać osobie, o którą się troszczy, ból. Może to dotyczyć zdyscyplinowania dzieci, stanowczości nauczyciela bądź wychowawcy wobec uczniów (wychowanków), pilnowania diety i ograniczenia ilości bądź rodzaju jedzenia w przypadku chorego, zaaplikowania szczególnie bolesnej procedury medycznej.

Dwie podstawy, które tworzą takie ethosowe, stwarzające zaufanie poznania, zdaniem Kępińskiego i Tischnera, to: chęć widzenia w drugim przede wszystkim jego człowieczeństwa i pewne powstrzymanie się od wyrokowania moralnego: „Nie sądźcie, abyście nie byli sądzeni” (Mt 7, 1). Można powiedzieć, że stwierdzenie XV-wiecznego myśliciela, Mikołaja z Kuzy, iż wobec Boga obowiązuje nas docta ignorantia (uczona niewiedza) w pewien sposób też obowiązuje wobec drugiego człowieka. Nie chodzi tylko o niewiedzę, powstrzymanie się od sądu, ale o „uczoną niewiedzę”, czyli o taką niewiedzę, która pozostaje, kiedy wiemy już wszystko na temat Boga/drugiego człowieka, czego możemy się dowiedzieć.

Możemy, a nawet musimy wydawać sądy dotyczące drugiego człowieka, szczególnie dotyczy to relacji opiekuna i osoby, o którą się troszczy: czy pacjent angażuje się w proces leczenia, czy osoba, której pomagamy jest uzależniona od alkoholu, pokazuje objawy jakiegoś zaburzenia psychicznego, itp. Niekiedy są to również sądy etyczne: osoba, którą się opiekujemy, oszukuje i kłamie, nie mówi ważnych rzeczy, kluczowych dla procesu leczenia i opieki itp. Również w takich sądach etycznych nie chodzi jednak o sam osąd, ale o zrozumienie drugiego i wyjaśnienie jego postępowania. W ocenie drugiego człowieka

$11 \quad$ J. Tischner, Myślenie według..., dz. cyt. 
powstrzymujemy się od sądów ostatecznych i całościowych, osądzamy tylko zachowanie człowieka, zewnętrzne przejawy, peryferie osoby. Nie mamy bowiem odpowiedniej wiedzy do całościowej oceny drugiej osoby. Taką wiedzę ma tylko Bóg, dlatego do niego należy sąd, jak o tym stanowczo mówi Pismo Święte Starego i Nowego Testamentu ${ }^{12}$.

Antoni Kępiński jako psychiatra dobrze wiedział o tych dylematach i tej osobowej głębi ludzkiego ducha, kiedy pisał, że jeśli celem psychiatry jest poznanie drugiego człowieka, to taki proces jest nieskończony: „Zawsze coś nowego można się o chorym dowiedzieć i zobaczyć go w innym świetle. Nie można bowiem człowieka poznać bez reszty" ${ }^{13}$. W swoich refleksjach na temat metody pracy psychiatry Kępiński dokonuje ważnego rozróżnienia pomiędzy poznaniem przyrodniczym i humanistycznym ${ }^{14}$. Poznanie przyrodnicze dotyczy „czegoś”, jest przedmiotowe: zewnętrzny obserwator chłodno określa warunki eksperymentu, aby dokonać jego możliwie wszechstronnego, obiektywnego zmierzenia, opisania za pomocą reguł matematycznych, co oznacza postawę zapanowania nad badanym przedmiotem. Poznanie humanistyczne, bardziej podstawowe od poznania przyrodniczego, również ma pretensje do powszechności i obiektywizmu, choć inaczej niż matematyczne poznanie przyrodnicze. W tym „bezpośrednim doświadczeniu”, poprzez wczucie, jesteśmy w stanie poznać stany psychiczne drugiej osoby, jej przyjazne, wrogie, bądź obojętne nastawienie, smutek bądź radość. Jak zauważa Kępiński, „poznanie typu przyrodniczego rozgrywa się w płaszczyźnie pochyłej. Obserwujący «patrzy z góry» na obserwowanego, spokojnie i na zimno przypatruje mu się, ustawia go według własnego planu. Czynnik emocjonalny z tego typu poznania jest wyłączony, zastępuje go czynnik wolicjonalny, przedmiot obserwowany jest poddany woli obserwatora. Stosunek między obserwatorem i obserwowanym jest jednostronny. Wyklucza się możliwość obserwacji i działania na obserwatora ze strony obserwowanego. Obserwator jest panem sytuacji”"15.

Poznanie między-ludzkie jest dwustronne; wymaga obustronnego emocjonalnego zaangażowania się nie dwóch przedmiotów, ale dwóch wolności. W spotkaniu z osobą, o którą się troszczymy, nie możemy przyjąć postawy przyrodnika, bo to oznaczałoby traktowanie drugiego jak przedmiot. Musimy nawiązać więź, ale równocześnie tak, aby „nie angażować się całkowicie tak, jak to dzieje się w zwykłych stosunkach międzyludzkich"16, towarzyskich. Jak podkreśla

\footnotetext{
Por. Ps 9, 8-9; Iz 3, 13-14; J 5, 27-30; J 8, 15-16.

A. Kępiński, Poznanie chorego, Warszawa 1989, s. 9.

Por. J. Maciuszek, Obraz człowieka w dziele Kępińskiego, Toruń 2015, s. 39-91.

A. Kępiński, Poznanie..., dz. cyt., s. 19.

A. Kępiński, Poznanie..., dz. cyt., s. 20.
} 
Kępiński, opiekun musi wytworzyć jakby „trzeciego, idealnego obserwatora”, który z dystansu, z zewnątrz może obserwować proces spotkania, nawiązywania emocjonalnej więzi pomiędzy opiekunem i pacjentem. Bez naruszania autentyczności tego spotkania „trzeci obserwator” musi określić granice emocjonalnego zaangażowania. Tylko taka synteza bliskości i dystansu, subiektywizmu i obiektywizmu, podmiotowości i przedmiotowości pozwala na prawdziwe zatroszczenie się o drugiego ${ }^{18}$.

Bardzo podobnie mówi o poznaniu pacjenta inny reprezentant Krakowskiej Szkoły Personalistycznej, wybitny lekarz, zmarły sześć lat temu profesor Andrzej Szczeklik. Współczesna nauka zawdzięcza swój sukces redukcjonizmowi, tzn. umiejętności badania poszczególnych zjawisk w izolacji od innych, ale w już „W ustroju ludzkim narządy są tak silnie ze sobą powiązane, że stosowanie do nich przybliżenia «układu izolowanego» wydaje się wątpliwe". Jak sugeruje krakowski lekarz i humanista, „należałoby wyjść poza «redukcjonizm», stworzyć nowe metody badania tych systemów, które trudno rozłożyć na elementy składowe”. Dlatego też medycyna jest czymś pomiędzy „nauką i sztuką"19.

\section{3. „Jeden drugiego brzemiona noście i tak wypełniajcie prawo Chrystusowe" (Ga 6, 2). Troska o kogoś, a nie o coś.}

Troska o drugiego jest zawsze troską o kogoś, a nie o coś. „Ktoś” to osoba, „coś” to kolejny przypadek, zadanie do wykonania. Troska o drugiego jest spotkaniem dwóch osób: tej, która się troszczy i tej, której troska dotyczy. Takie spotkanie jest paradygmatyczne dla bycia człowiekiem; każdy z nas znajduje się wielokrotnie zarówno w sytuacji troski o drugiego, jak też w sytuacji tego, którego dotyczy troska innych. Obie postawy są fundamentalnie ważne dla bycia człowiekiem: troszczyć się o drugiego, ale też pozwolić się sobą zaopiekować. Także ta druga postawa to również podstawowa ludzka umiejętność świadcząca o dojrzałości osoby. Ta umiejętność wydaje się być zresztą deficytowa w naszych narcystycznych czasach, kiedy miarą wartości człowieka jest jego wydajność i samodzielność, indywidualistyczna postawa „O mnie się nie martw, ja sobie radę dam”, Tuwimowska „Zosia Samosia”.

Józef Tischner w spotkaniu z drugim człowiekiem wyróżnia dwa ważne momenty: agatologiczny i aksjologiczny. Pierwszy moment to doświadczenie tragiczności istnienia drugiego, czyli tego, że każde ludzkie życie jest zagrożone.

\footnotetext{
17 A. Kępiński, Poznanie..., dz. cyt., s. 21.

18 Na temat relacji między postawą nie-oceniającą a obiektywizmem w trosce o drugiego, por. A. Kanios, Praca socjalna. Zagadnienia teoretyczne i metodyczne, Lublin 2014, s. 19-22.

19 A. Szczeklik, Katharsis. O uzdrowicielskiej mocy natury i sztuki, Kraków 2008, s. 62.
} 
Jak pisze filozof z Łopusznej, „aby pojawiła się tragiczność, wcale nie potrzeba, by zniszczenie stało się faktem. Już sama możliwość zniszczenia, sama nieznajomość wyniku walki dobra ze złem jest czymś tragicznym”20. To doświadczenie tragiczności ukazuje nam niedostatki świata dokoła, ale także odsłania osobistą odpowiedzialność za te niedostatki, cierpienie, ludzką bezradność, niewiedzę, samotność.

Wojtyłowa afirmacja, czyli uznanie osoby w drugim, w pewien sposób implikuje i zakłada Tischnerowskie doświadczenie agatologiczne. Patrzymy na innych ludzi wokół nas jako na tych, którzy zmagają się nie tylko z zewnętrznymi wymaganiami, ale także niosą w sobie cały ciężar życia wewnętrznego, wyborów, pytań i wątpliwości, dylematów moralnych. Pewna wyobraźnia pomaga nam w dostrzeżeniu wewnątrz każdego innego ,ja” tego, co ks. Tischner nazywał dramatem i ciężarem ludzkiej wolności. Ta wyobraźnia jest wyobraźnią etyczną; przymiotnik jest tutaj ważny co najmniej z dwóch powodów. Po pierwsze, ważną częścią doświadczenia agatologicznego jest świadomość, że drugi człowiek zmaga się w swoim wnętrzu z wyborami etycznymi, w których ludzka wolność sytuuje się wobec dobra i zła. W tych duchowych wyborach nierzadko stawka jest wysoka: zbawienie lub potępienie, wierność lub zdrada, sens bądź bezsens, możliwość minięcia się z celem swojego życia i powołaniem. Wyobraźnia w patrzeniu na drugiego ma charakter etyczny jeszcze z jednego powodu: jej „pojemność" i możliwości poznawcze zależą od etycznej dojrzałości poznającego podmiotu. Dopiero osobiste przeżycie i poważne potraktowanie wartości i dylematów moralnych umożliwia poważne potraktowanie i zrozumienie dylematów, wątpliwości, wewnętrznego rozdarcia drugiego człowieka. Mówimy tutaj o współ-czuciu, właściwej dla człowieka umiejętności nie tylko obserwowania człowieka z zewnątrz, ale także możności uczestniczenia w jego/jej życiu wewnętrznym, niesienia brzemienia ludzkich dylematów i wyborów.

Doświadczenie agatologiczne, czyli zobaczenie istnienia drugiego człowieka w świetle dobra (greckie agaton - dobro), zdaniem Tischnera prowadzi do drugiego doświadczenia: aksjologicznego, czyli wolnej decyzji, żeby zaradzić brakom świata przez podjęcie konkretnych działań. Myślenie aksjologiczne nie jest arystotelesowskim zdziwieniem i podziwem wobec harmonii świata, ale raczej buntem i niezgodą na niesprawiedliwość i ludzką krzywdę. Prowadzi do wyboru pomiędzy „człowiekiem, który zabija spotkane życie, a człowiekiem, który je pielęgnuje"21.

20 J. Tischner, Myślenie według..., dz. cyt., s. 533.

${ }^{21}$ J. Tischner, Myślenie według..., dz. cyt., s. 535. Właśnie o takim buncie i niezgodzie na niesprawiedliwą rzeczywistość mówi jedno z błogosławieństw wypowiedzianych przez Chrystusa w Kazaniu na górze: „Błogosławieni, którzy łakną i pragną sprawiedliwości, albowiem oni będą nasyceni” (Mt 5, 6). 


\section{Droga Brata Alberta: „Badźcie miłosierni jak Ojciec wasz jest miłosierny" (Łk 6, 36)}

Przejmujący obraz dojrzewania Tischnerowskiego doświadczenia agatologicznego i aksjologicznego znajdujemy w dramacie Karola Wojtyły Brat naszego Boga, który mówi o życiowej drodze Adama Chmielowskiego, św. Brata Alberta - założyciela zakonu albertynów ${ }^{22}$. Jest to obraz tym bardziej przejmujący, że powstał w latach tuż po II wojnie światowej - został napisany przez niezwykle młodego, dwudziestokilkuletniego autora, który z wielką dojrzałością patrzy na problemy ubóstwa, nierówności społecznej oraz różne obietnice zaradzenia tym problemom, w tym na propozycję marksistowską. Równocześnie, Wojtyła, pisząc o Bracie Albercie, kreśli w pewien sposób własną autobiografię. Używając słownictwa Tischnera, możemy powiedzieć, że młody Wojtyła ukazuje, jak Adam Chmielowski poprzez doświadczenie agatologiczne i aksjologiczne wzrasta ku postawie miłosierdzia. Doświadczenie agatologiczne to współczucie dla ubogich, mieszkańców miejskiej ogrzewalni. W wypowiedziach Adama odnajdujemy zarówno poruszające, pełne realizmu i współczucia opisy nędzy klientów miejskich przytułków, jak też pełne pasji oskarżenie elit społecznych, obojętnych wobec potrzeb ludzi, którzy nie potrafią sobie sami pomóc. W tym doświadczeniu jest zarówno współczucie, jak i Tischnerowski bunt wobec niesprawiedliwości stosunków społecznych: „Społeczeństwo jest chorym organizmem. Pozostaje ta wielka różnica, że chory organizm szybko musi się wydać, musi nie dociągnąć i opaść. Podczas gdy społeczeństwo długo może w sobie kryć chorobę. Raczej: może kryć się przed chorobą. Tak. Kryjemy się, uciekamy na małe wysepki zbytku, tzw. stosunków towarzyskich, tzw. układu społecznego, czując się w tym wszystkim bezpiecznie. Tymczasem - nie. Tymczasem to bezpieczeństwo jest wielkim kłamstwem, jest złudzeniem. To bezpieczeństwo wiąże nam oczy i zatyka uszy. Ale to wszystko musi wreszcie prysnąć" ${ }^{\prime 2}$.

Krytyczna diagnoza postawy beztroski i bezmyślności, jaką elity społeczne zajmują wobec zjawiska ludzkiej nędzy, prowadzi Adama do aksjologicznego pytania: co należy robić? Kluczowym wydarzeniem w procesie szukania odpowiedzi na to pytanie przez Adama, który w dramacie Wojtyły przedstawiony jest w trakcie malowania obrazu Ecce Homo, jest dostrzeżenie w innych ludziach, zwłaszcza ubogich i cierpiących, obrazu i podobieństwa Bożego. To nowe spojrzenie na innych ludzi, a zwłaszcza na ubogich, ma swoje konsekwencje. Po

${ }^{22}$ W tej części artykułu znajdują się wątki szerzej opracowane we wcześniej opublikowanej pracy autora: Idea solidarności w myśli Karola Wojtyły, „Ethos” 2004, nr 3-4, s. 67-83.

${ }_{23}$ K. Wojtyła, Brat naszego Boga, w: K. Wojtyła, Poezje i dramaty, Kraków 1979, s. 122. 
pierwsze, prowadzi Adama do realistycznej oceny wewnętrznej i zewnętrznej sytuacji nędzarzy. Przysłuchując się kłótni mieszkańców miejskiej ogrzewalni, która wybuchła wokół pytania: czy ubliżające jest dla nich określenie „dziad”?, Adam zaczyna rozumieć, że ubodzy chcą „czegoś więcej”: „nie mieć się za wyrzutków, wydobyć się z tego grzęzawiska”24. Właśnie dostrzeżenie u klientów miejskiej opieki społecznej potrzeby respektowania ich godności jest jednym ze źródeł oporu Adama wobec perswazji tajemniczego Nieznajomego (marksistowskiego agitatora), dla którego jedynym ważnym celem jest przekształcenie gniewu ubogich w rewolucję. Podczas agitacji rewolucyjnej w ogrzewalni zarówno dla Adama, jak też dla innych słuchaczy staje się jasne, że nieuświadomieni nędzarze mają być tylko instrumentem w rękach Nieznajomego, który chce ich użyć do osiągnięcia celów wskazanych przez rewolucyjną ideologię walki klas. Młody Wojtyła, może jeszcze nieświadomie, myślał już tutaj w kategoriach normy personalistycznej: „osoba jest takim dobrem, z którym nie godzi się używanie, które nie może być traktowane jako przedmiot użycia i w tej formie jako środek do celu".

Dramat Brat naszego Boga ukazuje Adama Chmielowskiego w trakcie dojrzewania przekonania, które zaowocuje dziełem jego życia - stworzeniem zakonnych zgromadzeń braci albertynów i sióstr albertynek; przekonania, że praca wychowawcza wśród ubogich, owo „wychowywanie gniewu” możliwe jest tylko przez solidarność i miłosierdzie. Podstawowym powodem odrzucenia rewolucyjnej agitacji Nieznajomego przez mieszkańców ogrzewalni - zresztą nazwanie tej postaci „Nieznajomym” przez Wojtyłę jest znamienne - był fakt, że jest on dla nich kimś obcym, przychodzi z zewnątrz: „Daleko od nas do ciebie”, „Ty pójdziesz, my pozostaniemy”, „Ten o nas wszystko wie, kto tu żyje wśród nas. Inni nie wiedzą nic". Wśród tego zgiełku zarzutów wykrzyczanych wobec nieznajomego rewolucjonisty Adam znajduje swój życiowy program: „Bądź jednym z nas". Jest to program solidarności z ubogimi, który Brat Albert zostawi założonym przez siebie zakonnym zgromadzeniom.

\section{Ciag dalszy}

Uniwersalne przesłanie Ewangelii zakłada fundamentalne przekonanie, że podstawowym doświadczeniem człowieka jest spotkanie drugiego jako osoby, przeżycie jego bliskości. Myśl, której ostatecznie nadano miano personalizmu, jest nurtem specyficznie chrześcijańskim i przez wieki rozwijała się nie tylko w refleksji filozoficznej, ale przede wszystkim w praktyce synów i córek Kościoła,

${ }^{24}$ K. Wojtyła, Brat naszego Boga, w: K. Wojtyła, Poezje..., dz. cyt., s. 150. 
którzy zrozumieli, że Ewangelia jest Słowem o Bogu, ale także Słowem o człowieku. Chodzi więc o postawę, która zawsze powinna być ważna dla chrześcijan i wszystkich osób identyfikujących się z etosem Ewangelii: wychodzenia z zamknięcia w sobie, aby dostrzec wartość człowieczeństwa drugiej osoby. Proces ten w myśli Karola Wojtyły jest nazwany afirmacją, czyli rozpoznaniem w drugim człowieku osoby; Józef Tischner, inspirowany myślą Antoniego Kępińskiego, rozwijał wątek poznania jako spotkania. Personalistycznie rozumiane poznanie nie jest więc stosunkiem obserwatora do przedmiotu, ale zawsze ma dwustronny charakter, który z obu stron angażuje całą osobę. Nawet w sytuacji konieczności wydania oceny (jak ma to miejsce w procesie leczniczym czy wychowawczym), u podstaw powinno być zawsze otwarcie na zrozumienie drugiej osoby i wyjaśnienie jej zachowania. To otwarcie można opisać w dwóch etapach: doświadczenia agatologicznego (zobaczenia drugiego w kontekście dobra), a następnie doświadczenia aksjologicznego, które jest próbą zaradzenia rozpoznanym brakom. To podwójne doświadczenie spotkania ma zawsze przełożenie na czyn, prowadzi do kształtowania postaw prawdziwie ludzkiej pomocy. Proces kształtowania tego ludzkiego i chrześcijańskiego miłosierdzia przedstawił Wojtyła, szkicując obraz przemiany Adama Chmielowskiego, Brata Alberta, w dramacie Brat naszego Boga.

Z odejściem mistrzów Krakowskiej Szkoły Personalistycznej nie zakończyła się jej historia. Ich uczniowie i uczniowie uczniów na nowo stawiają pytanie o osobę i personalistyczne podstawy troski o drugiego. W tym kontekście, w końcowych uwagach tego tekstu chcielibyśmy wskazać na twórczość Małgorzaty Opoczyńskiej. Szczególnie w swojej książce Genealogie psychoterapii autorka - opierając się na własnym doświadczeniu psychoterapeutki i w pewien sposób idąc dalej niż niektóre analizy zawarte w tym tekście - pyta o epistemologiczne, egzystencjalne i etyczne warunki prawdziwego spotkania z drugą osobą ${ }^{25}$. Agatologiczne i aksjologiczne doświadczenie drugiego, spojrzenie na drugą osobę jako możliwa forma przemocy i upokorzenia, poznanie, które uprzedmiotawia - to tylko niektóre z tematów powyższych refleksji, które u Opoczyńskiej znajdują ciąg dalszy, nową i intrygującą interpretację, domagającą się podjęcia i omówienia. Ale o tym już w innym miejscu.

25 M. Opoczyńska, Genealogie psychoterapii. Fragmenty dyskursu egzystencjalnego, Kraków 2016. Warto zajrzeć również do poprzedniej książki autorki Dialog innych albo inne monologi. Przypisy do psychoterapii, Kraków 2007. 